Review

\title{
Institutional Perspectives of Climate-Smart Agriculture: A Systematic Literature Review
}

\author{
Edmond Totin ${ }^{1,2}(\mathbb{D})$, Alcade C. Segnon ${ }^{2,3,4, *(\mathbb{1})}$, Marc Schut ${ }^{5,6}$ (1) , Hippolyte Affognon ${ }^{2}$, \\ Robert B. Zougmoré ${ }^{2,7}$, Todd Rosenstock ${ }^{8}$ (i) and Philip K. Thornton ${ }^{9}$ \\ 1 Ecole de Foresterie et d'Ingénierie du Bois, Université Nationale d'Agriculture du Benin, \\ Kétou BP 43, Benin; edmond.totin@gmail.com \\ 2 International Crops Research Institute for the Semi-Arid Tropics (ICRISAT), Bamako BP 320, Mali; \\ H.Affognon@cgiar.org (H.A.); R.Zougmore@cgiar.org (R.B.Z.) \\ 3 Institute for Environment and Sanitation Studies, University of Ghana, P.O. Box LG 209, \\ Legon, Accra, Ghana \\ 4 Faculty of Agronomic Sciences, University of Abomey-Calavi, Cotonou 01 BP 526, Benin \\ 5 International Institute of Tropical Agriculture (IITA), P.O. Box 1269, Kigali, Rwanda; M.Schut@cgiar.org \\ 6 Knowledge, Technology and Innovation Group, Wageningen University and Research, P.O. Box 8130, \\ 6700 EW Wageningen, The Netherlands \\ 7 CGIAR Research Program on Climate Change, Agriculture and Food Security (CCAFS), ICRISAT, \\ Bamako BP 320, Mali \\ 8 World Agroforestry Centre (ICRAF), P.O. Box 30677, Nairobi 00100, Kenya; T.Rosenstock@cgiar.org \\ 9 CGIAR Research Program on Climate Change, Agriculture and Food Security (CCAFS), \\ International Livestock Research Institute (ILRI), P.O. Box 30709, Nairobi 00100, Kenya; \\ P.Thornton@cgiar.org \\ * Correspondence: alcadese@gmail.com; Tel.: +229-97-327-830
}

Received: 22 May 2018; Accepted: 8 June 2018; Published: 13 June 2018

\begin{abstract}
Climate-smart agriculture (CSA) is increasingly seen as a promising approach to feed the growing world population under climate change. The review explored how institutional perspectives are reflected in the CSA literature. In total, 137 publications were analyzed using institutional analysis framework, of which $55.5 \%$ make specific reference to institutional dimensions. While the CSA concept encompasses three pillars (productivity, adaptation, and mitigation), the literature has hardly addressed them in an integrated way. The development status of study sites also seems to influence which pillars are promoted. Mitigation was predominantly addressed in high-income countries, while productivity and adaptation were priorities for middle and low-income countries. Interest in institutional aspects has been gradual in the CSA literature. It has largely focused on knowledge infrastructure, market structure, and hard institutional aspects. There has been less attention to understand whether investments in physical infrastructure and actors' interaction, or how historical, political, and social context may influence the uptake of CSA options. Rethinking the approach to promoting CSA technologies by integrating technology packages and institutional enabling factors can provide potential opportunities for effective scaling of CSA options.
\end{abstract}

Keywords: climate-smart agriculture; institutions; adaptation; mitigation; systematic review

\section{Introduction}

Global climate change is recognized as one of the greatest threats to agricultural productivity in several regions of the world [1]. Many African countries is projected to be severely compromised by climate variability and change in agricultural production, including access to food, the length of growing seasons, and yield potential [2]. Sub-Saharan Africa (SSA) has been particularly exposed 
to the impact of climate variability due to the high reliance on rain-fed agriculture in this region [3]. Harvell, et al. [4] have shown that the climate change impacts on agriculture will occur along with high population growth and change of consumption patterns. The world population is projected to be about 8 and 10 billion in 2020 and 2050 respectively [5]. With such a population trend, agriculture will require a significant transformation to ensure adequate food supplies for the growing population and meet the challenge of climate change [6].

Two major scenarios are considered to increase food production for the growing world population: (a) greater land clearing to expand the production area to meet the food demand, and (b) intensification on existing crop lands with an increased use of inputs, such as fertilisers and seeds. Regarding the fast expansion of urban areas, land scarcity is now a serious issue in many parts of SSA [7]. Technically, it would be relatively easier to increase food production and close the yield gaps through the intensification on existing crop lands with available technologies [8]. Therefore, the sustainable intensification of smallholder farming is a serious option for satisfying food requirements. The Climate Change, Agriculture and Food Security (CCAFS) program, an interdisciplinary CGIAR Research Program, seeks to achieve the sustainable intensification of food production and support global demand for food through the promotion of "climate-smart agriculture" (CSA).

The concept of CSA emerged as a promising way to secure food for the growing world population under climate change conditions [9]. The Food and Agriculture Organization of the United Nations FAO [10] defines CSA as "agriculture that sustainably increases productivity, enhances resilience, reduces greenhouse gases, and enhances achievement of national food security and development goals". The concept reflects an ambition to improve the integration of agriculture development and climate responsiveness. It aims to achieve food security and broader development goals within the context of a changing climate and increasing food demand [11]. The CSA includes both traditional and innovative practices and technologies that promote agricultural productivity and generate income. It also boosts resilience to climate change and mitigates greenhouse gas (GHG) emissions when possible. It includes three major pillars: (a) increasing agricultural productivity; (b) increasing adaptive capacity at multiple scales (from farm to nation); and (c) reducing greenhouse gas emissions [12]. While there is a consensus on the potential of the CSA to support global food and nutritional security in less-favored conditions [11-13], CSA scholars have different perspectives to approach the scaling of CSA options.

For decades, many countries have made significant investments in agriculture through successive generations of climate adaptation projects to increase the productivity of smallholder farmers (e.g., irrigation infrastructures; dissemination of improved agricultural packages) [14,15]. However, studies suggested that these projects have not achieved much success because, among other flaws, they focused on technology development assuming that this will be sufficient to stimulate agricultural intensification. However, by doing so, they underestimated the complexity of the institutional context within which the farmers and other actors in agricultural systems operate [16,17].

Over the past few decades, efforts to enhance the food systems productivity focused on a "technology push"-approach, assuming that significant productivity growth could be easily achieved through access to technologies $[18,19]$. Technologies then are transferred to the end-users with limited understanding of the local context under which these users operate, thus leaving out important issues such as access to market and credit [20]. Seemingly helpful options do not always receive the expected outcomes as the quality of the technology itself may not be the only factor that determines the adoption and the scaling [21]. Therefore, some authors, including Quisumbing and Pandolfelli [22] and Hounkonnou, et al. [23] argued that effective deployment of technological interventions in complex situations calls for a more comprehensive approach to stimulate sustainable transformation.

Overall, there has been a gradual shift from a technology-oriented approach to a more systems-oriented approach that considers the complexity of farming systems. This includes the full array of policy, market, political, and other institutional aspects that shape the context in which farming takes place. Several studies conducted in the agricultural innovation domain have shown that when 
focusing on technologies alone, one overlooks the enabling and constraining factors that determine whether technologies are available, accessible, and are able to make a difference for farmers [23-25].

An on-going systematic review is being conducted to evaluate the effectiveness of 73 promising farm-level technological management practices to achieve the CSA intended benefits and inform discourse on food, agriculture, and climate change [26]. This review targets CSA practices and technologies across five categories (agronomy, agroforestry, livestock, postharvest management, and energy systems) to assess their contributions to the three CSA pillars. This review focuses on the technologies, and ignores the institutional dimensions of CSA options. This paper adopts the system's perspective, and argues that institutional dimensions are paramount as they embody political agency, historical contingencies, and locally-specific dynamics of power that also play out in the adoption and the scaling of the CSA options. Therefore, the objective of this paper is to explore specifically whether and how institutional perspectives are reflected in the existing CSA literature. This study aims enlarge the scope of the previous syntheses on CSA practices conducted by Rosenstock, et al. [26] and to contribute to the broader debate about the potential role of institutions and institutional innovation in agricultural development in low- and middle-income regions. This is an issue which has only been investigated to a limited extent [27].

Following a detailed overview of the search protocol used to review the literature (Section 2), the article analyzes the thematic and geographical distribution of the available CSA literature and explores the different dimensions of the institutions reflected in the literature (Section 3). Finally, we highlight lessons emerging from this study and the major existing gaps in the literature that can inform future climate research (Section 4).

\section{Materials and Methods}

\subsection{Data Sources and Extraction}

To understand how institutional dimensions are reflected in CSA literature, we conducted the study by using the systematic review framework proposed by Berrang-Ford, et al. [28], which provides guidelines and formats for synthesizing and tracking climate change adaptation research. The framework includes, (a) the description of literature sources, (b) articulation of search terms and a detailed description of the search process, (c) the description of criteria for inclusion and exclusion, and $(d)$ the documentation of literature included and excluded.

\subsubsection{Description of Literature Source}

We used web-based search engines ISI Web of Science (WoS) and Scopus for literature identification. We limited the scope of these search engines because of their ability to provide easy access to complex search terms. They also provided extensive coverage both in terms on disciplines and the quality of their publications [29]. We purposely decided not to include grey literature such as institutional reports and based the study on peer review scientific literature.

In WoS, topic search was used to identify publications that refer to CSA in title, abstract, and author keywords. It was indexed in the Science Citation Index Expanded, the Social Sciences Citation Index or the Emerging Sources Citation Index. In Scopus, the Compound Field TITLE-ABS-KEY that searches abstracts, keywords, and article titles was used to identify CSA literature. The search was narrowed down to English language publications (in both search engines). The search considered all peer-reviewed articles, reviews, book chapters, books, and editorial material available in the search engines at the time of the search (from 1945 until February 2017).

\subsubsection{Articulation of Search Terms and/or Detailed Description of Search Process}

To identify relevant literature associated to CSA, we combined the search terms "climat* smart" OR "climat* friend" with descriptors (or keywords) related to agricultural sector (see Supplementary Materials Table S1 for a complete list of search strings used for the review). For the scope of this study, 
we partly based our methods on the work of Rosenstock, et al. [26]. In the study, we conceptualize agriculture as referring to crops, livestock, and fisheries sectors in the broadest sense, including soil/land and water management (see Table S1).

\subsubsection{Description of Criteria for Inclusion and Exclusion}

The preliminary search yielded 624 documents (including 225 publications from WoS and 399 publications from Scopus), which were exported into ENDNOTE X7 [30] for initial screening. After removing the duplicates and publication types other than article, review, conference paper, book chapter, book, or editorial material, 392 publications remained. Of these, 138 publications met relevance criteria after screening titles and abstracts based on our inclusion and exclusion criteria (Table 1). We performed a full text review for the 138 relevant publications to confirm eligibility for inclusion. Of the final list, one book chapter was not accessible and was excluded. The final list contains 137 publications.

Table 1. Inclusion and exclusion criteria for literature selection.

\begin{tabular}{ll}
\hline Inclusion Criteria & Exclusion Criteria \\
\hline Text in English & Text in languages other than English \\
\hline Publication type is article, review, or book chapter & $\begin{array}{l}\text { Publication type is other than article, review, or book chapter } \\
\text { (e.g., note, erratum, book review, conference paper) }\end{array}$ \\
\hline Focuses on the agricultural sector & $\begin{array}{l}\text { Focuses on sectors other than agriculture (e.g., energy and } \\
\text { transport sectors) }\end{array}$ \\
\hline $\begin{array}{l}\text { Addresses at least one of the CSA pillars (productivity, } \\
\text { adaptation and mitigation) }\end{array}$ & Addresses none of the CSA pillars \\
\hline Text includes sufficient detail to carry out data analysis & $\begin{array}{l}\text { Text does not provide sufficient detail to carry out } \\
\text { data analysis }\end{array}$ \\
\hline
\end{tabular}

In the next step, we studied in detail the 137 relevant CSA publications to identify (a) the CSA pillar(s) addressed; and (b) specific institutional dimensions of CSA options that are studied. The full text review targeted the publications' thematic focus, geographical scope, economic development status of the country of each publication, and CSA pillars addressed. We followed the World Bank's income-based distribution-low income, lower middle income, upper middle income, and high income [31] - to determine the development status of the countries. The income distribution is based on gross national income (GNI) per capita.

Next, we defined keywords (Table 2) to guide the analysis of institutional dimension, using an institutional analysis framework [32,33]. This framework subdivides between the following institutional dimensions: (a) 'knowledge infrastructure', relating to the way the creation and use of knowledge is organized (e.g., knowledge, research and development); (b) 'physical infrastructure', consisting principally of roads and telecommunications; (c) 'hard institution' refers to formal rules, regulations, and norms such as technical standards, labor law, and risk management rules; (d) 'soft institutions' relates to informal rules, such as social norms and values, culture and implicit rules; (e) 'interaction', calibrated by strength of connectivity, relation among actors as governments, NGOs and research institutes; and (f) 'market structures', relating to the position of and relations between market parties along the value chain. Following Schut, et al. [34], keywords were formulated progressively and examined as a proxy data source to reflect the features of institutions, recognizing that there are potential overlaps among some of the dimensions. Keywords were later clustered (for each dimension, when possible) to give more insights on how each institutional dimension was reflected in the literature. 
Table 2. Analytical framework and keywords used for institutional dimension analysis.

\begin{tabular}{|c|c|c|}
\hline Dimensions & Keywords & Cluster \\
\hline \multirow{5}{*}{$\begin{array}{l}\text { Knowledge } \\
\text { infrastructure }\end{array}$} & Extension system/advisory service & Agricultural extension system \\
\hline & Capacity building/training & \multirow{3}{*}{ Capacity strengthening } \\
\hline & Education & \\
\hline & Empowerment & \\
\hline & $\begin{array}{l}\text { Knowledge/experience } \\
\text { Information (access and/or sharing)/communication }\end{array}$ & $\begin{array}{l}\text { Knowledge and } \\
\text { communication }\end{array}$ \\
\hline \multirow{3}{*}{$\begin{array}{l}\text { Physical } \\
\text { infrastructure }\end{array}$} & Infrastructure & \multirow{3}{*}{ Infrastructure } \\
\hline & Roads & \\
\hline & Transport facility(ies)/asset (s) & \\
\hline \multirow{6}{*}{ Hard institutional } & Land or resource tenure/agreements/ownership & \multirow{3}{*}{ Resource tenure system } \\
\hline & Property right & \\
\hline & Traditional rights systems & \\
\hline & Policy (ies)/program (s)/rule/regulation/law & \\
\hline & $\begin{array}{l}\text { Subsidy (ies)/incentive (s)/financial Compensation/support } \\
\text { mechanisms/investment }\end{array}$ & Policy \\
\hline & Decision support system/planning/governance system & Governance \\
\hline \multirow{4}{*}{ Soft institutional } & Custom/tradition & \multirow{3}{*}{ Socio-cultural dimensions } \\
\hline & Norm (cultural)/cultural factors/trust & \\
\hline & Value/concern/attitude/belief & \\
\hline & Gender & Gender \\
\hline \multirow[b]{3}{*}{ Interaction } & Network/relationship/interconnection & \multirow{2}{*}{ Networking } \\
\hline & Membership/association/cooperative & \\
\hline & $\begin{array}{l}\text { Stakeholders engagement/partnership (public-private, } \\
\text { formal-informal, multi-stakeholders)/collective (or social) } \\
\text { learning/collective actions/mutual agreement } \\
\text { Multi-stakeholder platforms }\end{array}$ & Collaboration and partnership \\
\hline \multirow{6}{*}{ Market structure } & Inputs and technology (access/availability) & \multirow{5}{*}{ Inputs and support } \\
\hline & Labor & \\
\hline & Insurance & \\
\hline & Credit/financial support (access/availability)/capital & \\
\hline & Entrepreneurship & \\
\hline & $\begin{array}{l}\text { Market (access/availability/orientation/demand } \\
\text { Market information/competition/price/marketing } \\
\text { Supply/value chain/distributional channel } \\
\text { Contractual arrangement }\end{array}$ & Market and value chain \\
\hline
\end{tabular}

\subsubsection{Documentation of Literature Included and Excluded}

All the CSA publications found in the preliminary search were exported in a database, which contains information on authors, publication year, publication title, source title, publication type, authors' name, authors' keywords, and subject areas of each document. A database was also created for relevant publications containing additional information including CSA pillars addressed, thematic focus, and element/aspect of institutional dimension addressed. The list of included and excluded criteria are presented in Table 1.

\subsection{Data Analysis}

Descriptive statistics were used to present quantitative trends on CSA options in the literature and geographical distribution patterns. To test the associations between CSA pillars (e.g., productivity, adaptation, and mitigation) addressed and economic development status of publications' country, the Fisher exact test was performed, with significance reported at $95.0 \%$. Thematic content analysis was performed to examine how institutional dimensions was reflected in the relevant CSA publications. The institutional dimension analysis was guided by keywords (see Table 2) and performed electronically using Adobe Acrobat. Appearance of each institutional dimension keyword in the title, abstract, keywords and main body of the text (excluding figures, tables, captions, acknowledgement, and 
references) was quantified. Thus, the frequencies served as proxies to the level of importance attached to a particular institutional dimension. During the analysis, the meaning and use of each keyword was verified since specific keywords can have different meaning depending on the context in which it is being used [34]. All statistical analyses were performed using R software version 3.3.2 [35].

\section{Results}

\subsection{Distribution}

The initial 392 publications selected after the first screening included research articles $(72.7 \%$, $n=285)$, book chapters $(9.2 \%, n=36)$, conference papers $(7.6 \%, n=30)$, reviews $(7.4 \%, n=29)$, editorial materials $(1.8 \%, \mathrm{n}=7)$, and books $(1.3 \%, \mathrm{n}=5)$. The publications' years ranged from 1991 to 2017 . While the average number of publications per year was 18 , about $89.0 \%(n=349)$ of the documents were published after 2008, which was the period where the CSA concept emerged in the literature (Table 3). The top-five publication sources included agricultural systems $(3.1 \%, n=12)$, agriculture and food security $(2.5 \%, \mathrm{n}=10)$, energy policy $(2.3 \%, \mathrm{n}=9)$, climate policy $(1.3 \%, \mathrm{n}=5)$, and land use policy $(1.3 \%, \mathrm{n}=5)$.

Table 3. Composition of climate-smart agriculture and institutional-oriented climate-smart agriculture publications.

\begin{tabular}{|c|c|c|c|}
\hline & $\begin{array}{l}\text { All Publications (Climate } \\
\text { Smart/Friendly Literature) }\end{array}$ & $\begin{array}{l}\text { CSA Relevant (Agriculture) } \\
\text { Publications }\end{array}$ & $\begin{array}{l}\text { CSA-Institutional-Oriented } \\
\text { Publications }\end{array}$ \\
\hline Number of publications & $100.0 \%(\mathrm{n}=392)$ & $35.0 \%(\mathrm{n}=137)$ & $19.4 \%(\mathrm{n}=76)$ \\
\hline Range of publication years & 1991-2017 & 2008-2017 & $2011-2017$ \\
\hline Average publication per year & 18.67 & 15.22 & 10.85 \\
\hline $\begin{array}{l}\text { Top- } 5 \text { publication sources } \\
\text { (\% of total) }\end{array}$ & $\begin{array}{l}\text { Agricultural systems }(3.1 \%) \\
\text { Agriculture and food } \\
\text { security }(2.5 \%) \\
\text { Energy policy }(2.3 \%) \\
\text { Climate policy }(1.3 \%) \\
\text { Land use policy }(1.3 \%)\end{array}$ & $\begin{array}{l}\text { Agriculture and Food Security }(7.3 \%) \\
\text { Agricultural Systems }(6.6 \%) \\
\text { Journal of Cleaner Production }(2.9 \%) \\
\text { Regional Environmental } \\
\text { Change }(2.9 \%) \\
\text { Nutrient Cycling in Agro } \\
\text { Ecosystems }(2.2 \%)\end{array}$ & $\begin{array}{l}\text { Agriculture and Food } \\
\text { Security }(11.8 \%) \\
\text { Agricultural Systems }(9.2 \%) \\
\text { Regional Environmental } \\
\text { Change }(5.3 \%) \\
\text { Food Security }(2.6 \%) \\
\text { Gender, Technology, and } \\
\text { Development }(2.6 \%)\end{array}$ \\
\hline
\end{tabular}

Main subject areas covered in the 392 publications were respectively environmental science ( $45.2 \%, \mathrm{n}=177)$; agricultural and biological sciences $(34.4 \%, \mathrm{n}=135)$; social sciences $(25.0 \%, \mathrm{n}=98)$; energy $(15.6 \%, \mathrm{n}=61)$; engineering $(11.7 \%, \mathrm{n}=46)$; and economics, econometrics, and finance $(11.2 \%, n=44)$ (see Supplementary Materials Figure S1 for the overall subject areas covered by the CSA publications).

\subsection{Climate-Smart Agriculture Focused Literature}

Of the 137 CSA focused publications, $80.3 \%(n=110)$ were research article, while review and book chapter covered respectively $11.7 \%(n=16)$ and $8.0 \%(n=11)$. Although, on average around 15 CSA focused publications were made per year, and about $92.7 \%(n=127)$ of CSA publications were published after 2012. The top-five publication sources were Agriculture and Food Security $(7.3 \%, \mathrm{n}=10)$, Agricultural Systems $(6.6 \%, \mathrm{n}=9)$, Journal of Cleaner Production $(2.9 \%, \mathrm{n}=4)$, Regional Environmental Change $(2.9 \%, \mathrm{n}=4)$, and Nutrient Cycling in Agroecosystems $(2.2 \%, \mathrm{n}=3)$.

In terms of geographic coverage, India was the most represented country in the CSA literature, with 13 publications [36-41], followed by Tanzania $(n=10)$ [42-45], Germany $(n=8)$ [46-48] and Malawi $(n=7)$ [49-51] (see Figure S2 for the distribution of the CSA related publication across countries). Some publications however, did not make specific reference to a country or region $(n=21)$ and provided generic conceptual development $[11,52,53]$.

Overall, Africa was the most targeted continent in the CSA literature with about 46 out of the 137 publications that met the inclusion criteria for selection, followed by Asia $(n=32)$, Europe $(n=27)$, 
and America $(n=16)$. Within the African continent, the sub-regions of Eastern Africa and Western Africa were the most targeted with 40 and 10 publications, respectively. The CSA publications obtained in Southern Asia and South-Eastern Asia sub-regions were 19 and 6, respectively. In Europe, Northern Europe, and Western Europe were the most represented sub-regions, with 16 and 10 publications respectively. In the Americas, South, Central, and Northern America were fairly equally represented with respectively seven, six, and five publications.

Regarding the specific agricultural related focus, the review shows that the climate perspective is reflected in the CSA literature from different angles, ranging from farm-scale agricultural practices [54-56] to food supply chains and food systems [57,58].

Based on the CSA pillars addressed, about $32.1 \%(n=44)$ of the publications addressed simultaneously the three CSA pillars-productivity, adaptation, and mitigation [12,59-61]. About $26.3 \%(n=36)$ emphasized on mitigation only $[47,48,62]$, while $21.9 \%(n=30)$ on both productivity and adaptation issues $[42,63,64]$. A relatively limited number of the publications combined productivity and mitigation pillars $(6.6 \%, \mathrm{n}=9)[49,65,66]$; adaptation and mitigation $(2.9 \%, \mathrm{n}=4)[67-70]$; and in adaptation alone $(6.6 \%, \mathrm{n}=9)$ [71-73].

A cross analysis of the pillars addressed and the economic development status of the country in which the study has been conducted indicated that publications addressing either adaptation or productivity pillars were more likely to come from low income and lower middle income countries, while publications reporting on mitigation were more likely to come from high income countries $(p<0.0001$, Fisher's exact test, Figure 1$)$. Sixty-six percent $(66.7 \%, \mathrm{n}=24)$ of publications solely addressing mitigation were from high income countries compared with $2.8 \%(\mathrm{n}=1), 11.1 \%(\mathrm{n}=4)$ and $16.7 \%(\mathrm{n}=6)$ from low, lower-middle, and upper-middle income countries, respectively. Publications addressing specifically productivity dimension were equally $(40 \%, \mathrm{n}=2)$ from low and lower-middle income countries compared with $20 \%(\mathrm{n}=1)$ from high income countries. Regarding adaptation pillar, $22 \%(22.2 \%, \mathrm{n}=2)$ of adaptation publications were from high income countries, while $33.3 \%(\mathrm{n}=3), 55.5 \%(\mathrm{n}=5)$ and $11.1 \%(\mathrm{n}=1)$ from low, lower-middle, and upper-middle income countries, respectively.

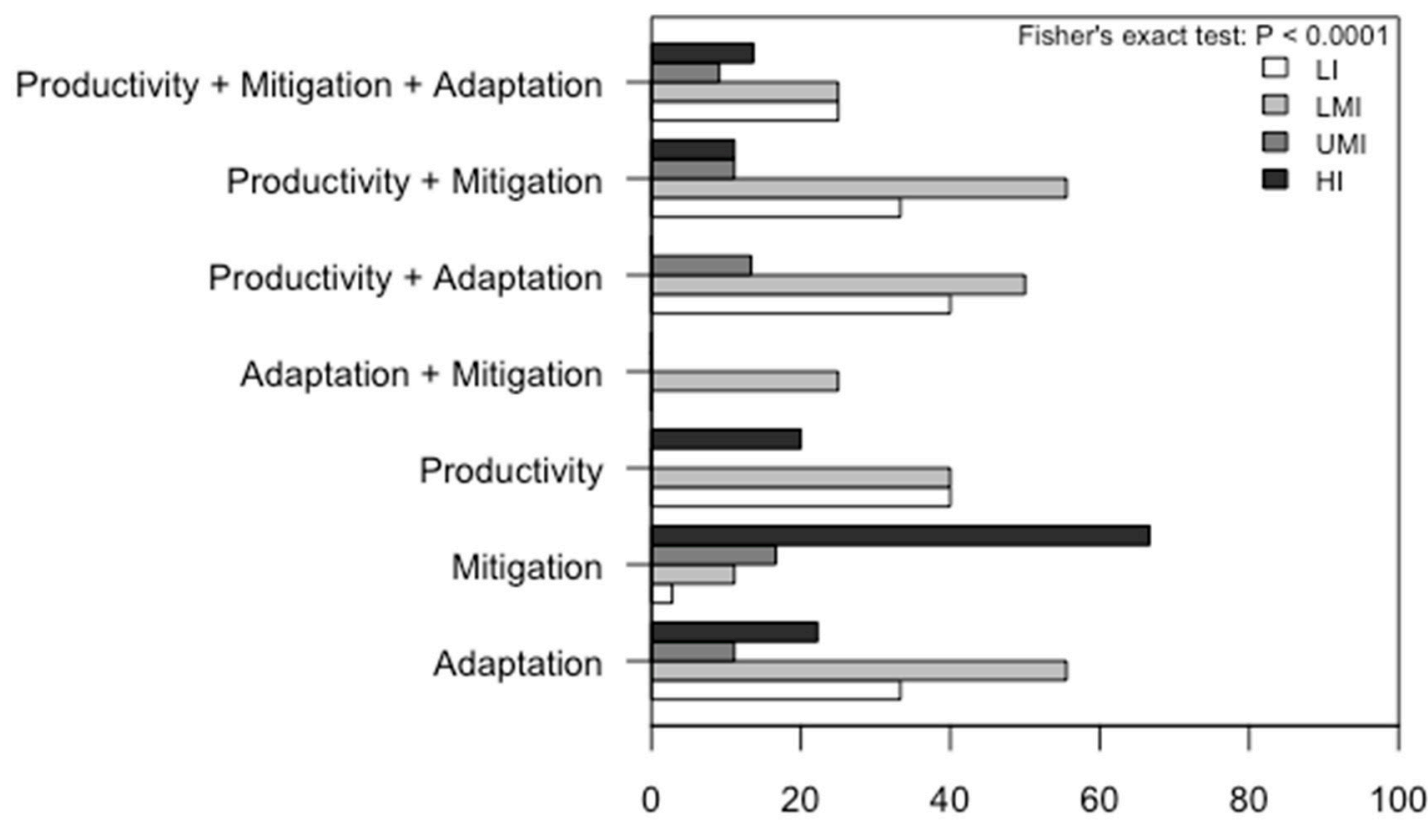

Percentage (\%)

Figure 1. Correlation of CSA pillars addressed and the economic development status of the country ( $\mathrm{LI}=$ low income; $\mathrm{LMI}=$ lower-middle income; $\mathrm{UMI}=$ upper-middle income; $\mathrm{HI}=$ High income). 
Obviously, in developed countries (e.g., Europe and North America), most of the literature on the climate change and global warming inevitably turns to the responsibility industrialized countries bear for having contributed to temperature change by the burning of fossil fuels $[48,62]$. The literature, particularly focuses on climate change mitigation and puts emphasize on the obligations of industrialized states to reduce their emissions of greenhouse gases mainly carbon dioxide produced and to help poor countries do likewise $[47,74]$. They often argue that global warming is a matter of international justice, fairness, and equity [75,76]. In the developing countries, however (e.g., Sub-Saharan African and South America), where climate change and variability are among the major challenges to the food systems, the literature mainly focuses on the improvement of farming practices and access to resources to increase the productivity of agriculture and to secure food for the growing population $[71,73,77]$. In general, the development status of a country or a region seems to influence the way the country approaches the climate change issues, either through mitigation (mostly for the developed countries) or adaption and productivity increased perspectives, which are the priorities for developing countries [53].

\subsection{Institutional Perspective in CSA Literature}

The in-depth analysis of the CSA literature shows that about $55.5 \%(n=76)$ of the publications make specific reference to the institutional dimensions, albeit from diverse perspectives including knowledge and physical infrastructures, market structure, soft and hard institutions, and interactions as illustrated by Figure 2 (see Table S2 for complete overview of CSA publications according to the institutional dimension addressed). Articles were written from 2011 onwards, with on average 10 publications per year and about $85.5 \%(n=65)$ that have been published after 2013 . The top-five institutional-focused publication sources included, Agriculture and Food Security $(11.8 \%$, n = 9); Agricultural Systems $(9.2 \%, \mathrm{n}=7)$; Regional Environmental Change $(5.3 \%, \mathrm{n}=4)$; Food Security $(2.6 \%, \mathrm{n}=2)$; and Gender, Technology, and Development $(2.6 \%, \mathrm{n}=2)$. In this section, we analyze the specific institutional aspects reflected in the existing CSA literature based on institutional analysis framework [32].

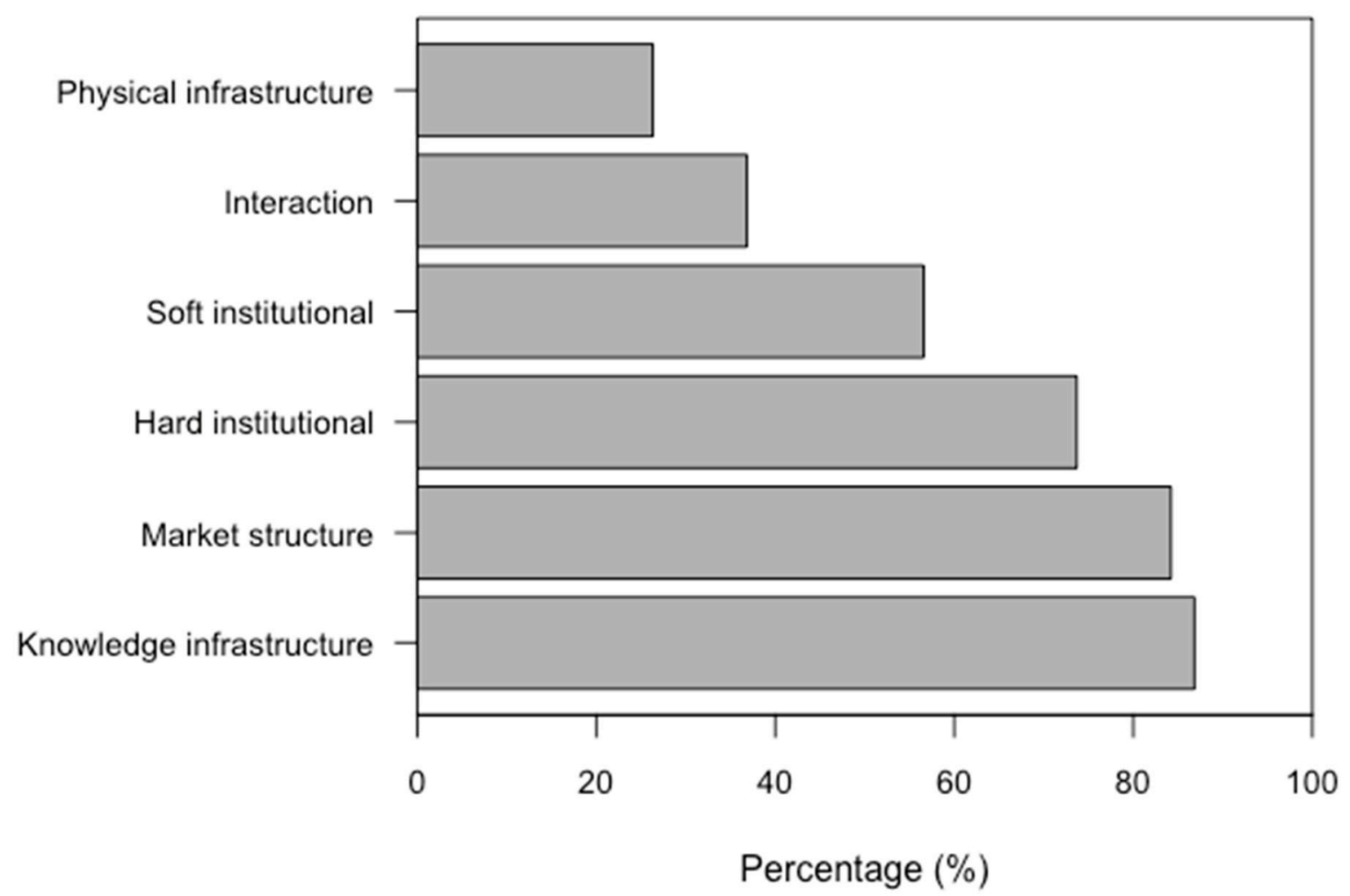

Figure 2. Institutional dimension reflected in the CSA literature. 


\subsubsection{Knowledge Infrastructure}

The knowledge infrastructure dimension was addressed in $86.8 \%(n=66)$ of the publications. Some of these publications $(40.8 \%, \mathrm{n}=31)$ targeted the factors that create enabling condition for scaling CSA technologies. A set of articles conclude that despite the technical feasibility and the biophysical performances of CSA technologies, their uptake can remain low if the users, for example smallholder farmers, do not perceive the direct benefits they can gain from the technology. For farmers, the first goal of adopting CSA technologies is about the profits they can have from using the technologies, rather than the positive environmental benefits $[38,78,79]$. Such reward schemes represent a big boost for the farmer livelihoods and provide incentives for them to make decisions in favor of the CSA technologies [60]. This is similar to what happens at the decision stage of adoption processes as described by Rogers [80] which involves the weighing of benefits, disadvantages, and trade-offs to inform the decision of adoption or rejection of a proposed technology. Clearly, the environmental impact is not always the target of technology users, but mainly how the externalities generated from the use of CSA technologies contribute to household needs-both food security and household incomes. Likewise, Alem, et al. [42] presented the system of rice intensification (SRI), which is widely used in low-rainfall areas. The increased use of SRI is not related to the climate smart label of the technology, but people adopt the technology because it generates significant benefits for users. On average, participation in SRI increases yield per acre by about $58 \%$ and it requires less water [42]. This also results in a substantial reduction in the amount of methane emitted to the atmosphere, which is the embedded climate impact [81]. Kpadonou, et al. [13] also makes a similar conclusion, estimating that the availability of labor, security over land tenure, and capacity building are the major drivers of farmers' decisions to adopt CSA technology. Again, the positive environmental outcome of the CSA technology alone is not enough to stimulate its uptake.

Another category of publications $(81.6 \%, \mathrm{n}=62)$ provided a more comprehensive understanding of challenges surrounding the adoption of CSA practices and emphasized the need for additional support, such as enabling policy to facilitate their uptake $[13,82,83]$. Along the same lines, Dougill, et al. [51] and Pulkkinen, et al. [57] highlighted the role that knowledge, communication, and capacity building all play in stimulating and enhancing the adoption of CSA options.

\subsubsection{Hard Infrastructure}

Regulation and policy featured in approximately $73.7 \%(n=56)$ of the publications. The articles referred to the resource tenure $[12,49]$, the policy $[61,84]$, and governance $[85,86]$. They mapped the differences of priority setting between developed and developing countries and discuss how climate is mainstreamed in agriculture policies, negotiations, and strategies developed to achieve more sustainable outcomes [87]. For the effective implementation of the CSA options at a larger scale to meet the projected rise in global food demand, scholars also emphasized the need for a comprehensive regulatory framework to incentivize the agricultural sector to convert from conventional to more climate smart practices $[61,88,89]$.

\subsubsection{Market Structure}

Almost $84.2 \%$ of the CSA literature $(n=64)$ addressed market related issues. These publications show that building resilient food systems for vulnerable farmers should focus not only on improving yields and on use of drought tolerant varieties, but also on creating enabling conditions for access to production inputs (e.g., seed, fertilizer, labor), post-harvest facilities [90], and market outlets [42,91]. Uncertain markets and variable prices very often determine the users' decision to adopt or not a given CSA technology. Alem, et al. [42] examines the influence of the rice market price and concluded that, even SRI indeed improves yield in rain-dependent areas, its profitability hinges on the market price farmers. Harvey, et al. [91] assert the important role of enabling institutions-the market-when exploring plausible options to strengthen the adaptive capacity of smallholder farmers. They concluded 
that although farmers use a variety of risk-coping strategies, these are insufficient to prevent them from food insecurity. This is a result of poor articulation of their adaptive strategies with the wider institutional setting, such as a reliable financing system and market facilities.

Some of the publications, including works of Douxchamps, et al. [64] and Fischer, et al. [36] show that the increased use of the CSA options could improve the food security status of rural households and reduced their vulnerability resulting in a more stable cash flow. These publications often point to the availability of remunerative market outlets and access to inputs as pre-conditions for the increased use of the CSA options $[51,64,89,92]$. The CSA related market publications also examined the major economic barriers that hinders the adoption and diffusion of CSA innovations such as the poor access to financial support [51]. The high cost of some of the CSA technologies is a major barrier, as smallholder farmers can hardly afford them. Other publications, including [93], studied the willingness of the consumers to pay more for products resulting from the climate smart farming.

\subsubsection{Soft Institutions}

Soft institutions are reflected in about $55.3 \%(n=42)$ of the publications, focusing on gender [94-97] and other socio-cultural dimensions [86,89]. For instance, Njeru, et al. [86] assessed the effect of various traditional water harvesting practices and integrated soil fertility management technologies for enhanced sorghum productivity in lower and drier parts of Central Kenya. Much of these publications also analyzed locally developed strategies to cope with changing climate conditions $[59,98]$. Even though Nordic countries are self-sufficient in meat production, Aby, et al. [59] established that there is a high need for more local initiatives and innovative climate-smart agriculture to accommodate human population growth and climate change challenges.

Approximately $32.9 \%$ of the publications $(n=25)$ reflected on how the diversity of the local context within which CSA options are promoted can affect the direction and magnitude of potential outcomes generated $[94,99,100]$. They recommend considering a critical background analysis of social, historical, and cultural conditions when promoting the CSA options. A number of these publications also show that the CSA diffusion initiatives cannot work in isolation and should be part of wider institutional interventions (e.g., government and large scale programs) to capture additional and supportive opportunities [96,101].

\subsubsection{Interactions}

About $36.8 \%$ of the publications $(\mathrm{n}=28)$ made reference to interaction through networking $(18.4 \%$, $\mathrm{n}=14)$ [102] and partnership $(30.2 \%, \mathrm{n}=23)[44,103]$. The publications explored how the growing pool of investment in climate change offers an opportunity for the local communities to build their capacities and develop innovative partnership with government organizations [44,102]. An illustrative case of win-win public-private collaboration was formed between farmers, private-milk-processing enterprises and a public research institution in Tanzania to improve the standard of the locally produced milk. It also guarantees a remunerative market outlet of the surplus milk to larger and more distant markets Msalya, et al. [44]. The development of innovative market opportunities around the CSA options can stimulate smallholder farmers to engage in strategic partnership with key stakeholders such as universities and research centers. These partnerships can lead to the creation of new activities; for example, the establishment of climate-smart goat's milk processing and dairy goat maintenance in Tanzania as the outcome of joint collaboration between Universities, research entities, and farmers' organization [44]. Likewise, regarding the plausible impacts of global warming and continued uncontrolled release of greenhouse gasses and their implications for the livestock industry, no single organization (or entity) can perform the needed research and the implementation thereof on its own. Scholtz, et al. [98] recommended collective innovations and joint actions of relevant stakeholders with the objective to share research expertise and information, build capacity, and conduct research and development studies, should be a priority. This option is similar to what Pomeroy, et al. [104] have also recommended, stressing on collective and more integrated actions and 
the capacity building of fishery members to enhance their resilience to climate change. In general, this category of publications examined the potential role of private sector and partnership in the diffusion of CSA to small-scale farmers.

\subsubsection{Physical Infrastructure}

There are relatively limited CSA publications $(26.3 \%, n=20)$ that reflected on issues linked to physical infrastructure. The publications that address physical infrastructure make reference to roads and post-harvest facilities $[60,61,71,97]$. These publications highlight the impacts that climate change manifestations have on infrastructure for post-harvest storage and processing, and subsequent transport networks. For most of these publications, modern infrastructure facilities reflect the growing concern over climate change by adopting engineering principles and guidelines for greater adaptation to emerging environmental challenges.

\section{Discussion}

Research and development scholars establish that technology-oriented interventions alone may not be sufficient to sustainably address the challenges of agriculture and climate change [21-23,105]. Many agrarian systems are still suffering from the extreme climate events, despite the extensive research on climate-coping options, including existing sophisticated agricultural modelling that predicts plausible future pathways. It elucidates the uncertain characteristic of climate events and the limitation of the technology-oriented approach to address complex issues as climate change. It is clear that setting sustainable solutions in reducing risks to food security will require coordinated and systematic responses of many actors across levels [106]. Below are the main lessons and knowledge gaps identified from the CSA review.

\subsection{Emerging Lessons}

The review shows that the interest in the institutional dimension of the CSA options started in 2011 and focused on knowledge distribution, market, and policy aspects $[48,60,84]$. This interest has expanded gradually to address new perspectives such as gender and social differentiation in adoption of climate-smart agricultural practices [97]. The asymmetric access to extension officers, agricultural services, and information remains a major barrier that hinders the effective use of the CSA options. Part of the literature elucidates how the diversity of the local context can orient the scale and the amplitude of interventions [94]. New perspectives reflected in the literature also include the emergence of partnerships with a wide diversity of stakeholders, which offers an opportunity for the local communities to capture resources and build their capacity [102].

Regarding the institutional analysis, about $55.5 \%(n=76)$ of the CSA publications studied in this review used the systems approach by including institutional perspective in their analysis. Market structure and knowledge infrastructure aspects were the most frequent institutional dimensions reflected in the literature. They specifically discussed the key role that the availability of market opportunities can play in the uptake of the CSA technologies and practices. Scholars demonstrate that creating enabling market conditions will contribute to reducing the risk for potential users to invest in the CSA options [36,60]. For example, the existence of remunerative market opportunities could stimulate farmers to use the promoted CSA technologies as they may be guaranteed that the resulting product will be sold at a relatively good price. This analysis confirms Drucker and Noel [107] perspective according to which technology is seen as a kind of 'artefact', and it is among the market mechanism that the technology is transformed into innovation. It implies that, on its own, a technology is not sufficient. It helps to create value only when it meets an enabling market opportunity [108].

The CSA concept aims at increasing productivity and resilience, reducing/removing GHGs, and enhancing the achievement of food security and development goals. While theoretically the CSA concept is defined with these three objectives, in practice however, it is not always addressed as such. Some climate scholars assert that actions related to either mitigation, adaptation, or increase of crop 
productivity have potential overlaps $[109,110]$. The gap between what CSA theoretically is and how it is implemented in practice could be linked to methodological challenges. As the boundary among the three pillars intersect in many ways, it may be necessary to assess the potential of a given practice by pointing simultaneously to the three pillars. To deepen the understanding of climate priorities and options, further works may be needed to design a methodological framework that allows a systematic assessment of the three pillars for CSA options. Thus, offering a more conducive context for implementation.

The review shows that in developed countries, much of the research and development actions emphasized on the reduction of greenhouse gas emissions with less commitment in adaptation actions. In the developing countries, however, interventions mainly focused on setting an enabling condition for increased crop productivity to ensure resilience to climate change $[50,51,111]$. In general, the development status of a country seems to influence the way that climate change challenges are addressed, either through mitigation (mostly for the developed countries) or adaptation and productivity-increase lenses [53].

\subsection{Knowledge Gaps}

While the market and knowledge dimensions are well documented in the existing CSA literature, there are a number of gaps that still exist: (a) limited attention to contextual and cultural factors; (b) relatively poor public-private partnership to support the scaling of the CSA options; and (c) a gap in physical infrastructure analysis. These institutional dimensions have not been given adequate attention in the CSA literature.

There has been little research to understand the role of local rules, historical legacies, cultural influences, social identities, and political competition in the uptake of CSA technologies. Many scholars argue that the institutional context in which a given technology is promoted is inevitably a component that shapes the uptake process $[23,112,113]$. For example, in their analysis of the drivers of technology transfer, Kedia and Bhagat [114] acknowledge that better understanding of the cultural constraints is important to design technologies that meet users' expectations and values. Also, many government interventions fail in their attempt to replicate the Asian Green Revolution in Sub-Saharan Africa, among others, because these initiatives have underestimated the potential of social, political, cultural, and historical contexts [115]. The success of the Green Revolution in Asia was possible due to structurally-, historically-, and socially-constructed enabling environment that lead to crop productivity growth [116]. The recognition of the institutional dynamics and relations that link technologies to the broader context in which they are operating is important to catalyze their effective use. This contextual analysis has not been given adequate attention in the current CSA literature.

The review highlights the little interest of existing literature to the "interaction", between private sector and public government. This is an important gap, specifically in the context of Sub-Saharan Africa, where most governments reduced their public expenditures in agriculture based on the new orientation after the structural adjustment reforms [117]. These reforms happened along with global food and financial crises, changing market structure, and climate challenges [118]. In such a dynamic context, stimulating the interaction among key players to attract more investment flows, from the private sector may be an opportunity to fill public investment gaps. It also has the potential to channel capital needed for agricultural and rural development [119]. This in turn will accelerate the replication of climate-resilient technologies and services in core development sectors [119]. Unfortunately, in SSA, private sector supports to agricultural development in general and CSA technologies are weak and often seen as a negative business practice. However, strong public-private partnerships appear to be a promising alternative to create business opportunities for upscaling CSA technologies. A recent innovative public-private experiment is being constructed with Manobi $\odot$, a private company that offers a portfolio of integrated agricultural-climate services to the most vulnerable communities to cope with climate challenges [87]. Evidence of the value of public-private interaction has not been captured much in the CSA literature. Few publications related to public-private connection exist $[44,57,103]$, 
but there is still limited understanding of how this kind of cooperation adds value to the upscaling of the CSA options.

The review demonstrates a relatively poor articulation of physical infrastructure in CSA literature, which overlooks an important portion of this discourse. Many research findings, including the work of Platteau [120] highlighted the significant role that physical infrastructures such as roads and rural communication play in agricultural development. Overall, about $26.3 \%(n=20)$ of the selected literature made specific reference to the physical infrastructure (e.g., roads and post-harvest facilities) $[60,61,71,97]$. Haggblade, et al. [121] observed that investments in rural infrastructure, such as roads, can stimulate the reduction of transportation costs, increase farmers' access to markets and lead to substantial agricultural expansion. Even though it is recognized that infrastructure investment has a strong impact on rural incomes [121], major infrastructural issues are not addressed yet in the CSA literature.

The works of Rinaldi, et al. [122] indicated that irrigation is one of the critical components that affects the agricultural productivity and helps to mitigate the effect of climate variability in a significant manner. Irrigation has great potential to support adaptation to climate variability and change in cropping systems. Upscaling irrigation-based CSA options will likely result in simultaneously adaptation and productivity benefits. However, there are currently limited empirical studies on the irrigation system to support crop productivity $[73,123,124]$. There is also limited information to policy decision-making on adaptation and food security in this challenging climate context.

\section{Conclusions}

The concept of CSA is becoming a booming topic in agricultural development and climate change communities. It emerges as a promising package to secure food for the growing world population exposed to climate uncertainty and increasing food demand. Many of the CSA interventions continue to focus on the development and diffusion of technological packages to increase the productivity of smallholder farmers. A growing body of literature suggested that technology-oriented interventions alone may not be enough to achieve sustainable agricultural transformation. This is due to the complexity of the institutional context within which actors in agricultural systems operate. Using the innovation system framework, the study analyzed 137 peer review CSA publications, and shows that interest in institutional perspectives of CSA technologies has gradually grown over the years. Although the existing literature acknowledges the importance of some institutions in the uptake of CSA technologies (e.g., market), other perspectives such as the engagement of private sector in agricultural development have received less attention. Another major gap in the current literature relates to the documentation of the synergies and tradeoffs among the three pillars of CSA and the poor attention on the role of the contextual factors-historical legacies, cultural influences, and political competition-in the scaling of CSA options. The review concludes that more attention is needed for the institutional and political dimensions of CSA technologies. Rethinking this approach to promote CSA technologies by building both on technology packages and institutional enabling context can provide potential opportunities for effective scaling of CSA options. Such knowledge is critical to improving the design of CSA research and supportive policy.

Supplementary Materials: The following are available online at http:/ /www.mdpi.com/2071-1050/10/6/1990/ s1, Figure S1. Subject areas covered by the CSA agricultural oriented publications analyzed title; Figure S2. Geographic distribution of the CSA related publications; Table S1. Description of search strings used for CSA literature identification; Table S2. Categorization of CSA publications according to institutional dimensions.

Author Contributions: Conceptualization, E.T., A.C.S., and M.S.; Methodology, E.T., A.C.S., and M.S.; Formal Analysis, E.T. and A.C.S.; Investigation, E.T. and A.C.S.; Data curation, A.C.S.; Writing-original draft preparation, E.T. and A.C.S.; Writing-review and editing, E.T., A.C.S, M.S., H.A., T.R., R.Z., and P.K.T.; Visualization, E.T., A.C.S., M.S., and T.R.; Supervision, R.Z. and P.K.T.

Funding: This research received no external funding. 
Acknowledgments: The authors acknowledge the CGIAR Fund Council, ACIAR (Australia), European Union, International Fund for Agricultural Development (IFAD), New Zealand, The Netherlands, Switzerland, UK, and Thailand for funding to the CGIAR Research Program on Climate Change, Agriculture and Food Security (CCAFS). This work was also carried out under the Adaptation at Scale in Semi-Arid Regions (ASSAR) consortium. ASSAR is one of four consortia under the Collaborative Adaptation Research Initiative in Africa and Asia (CARIAA), with financial support from the UK Government's Department for International Development (DFID), and the International Development Research Centre (IDRC), Ottawa, Canada. The views expressed in this work are those of the creators and do not necessarily represent those of the UK Government's Department for International Development, the International Development Research Centre, Canada or its Board of Governors. The authors thank Beda Adza Maretha and Essegbemon Akpo for providing critical comments and editorial assistance.

Conflicts of Interest: The authors declare no conflict of interest.

\section{References}

1. Niang, I.; Ruppel, O.C.; Abdrabo, M.A.; Essel, C.; Lennard, C.; Padgham, J.; Urquhart, P.; Descheemaeker, K. Africa. In Climate Change 2014: Impacts, Adaptation, and Vulnerability. Part B: Regional Aspects. Contribution of Working Group II to the Fifth Assessment; Cambridge University Press: Cambridge, UK; New York, NY, USA, 2014; pp. 1199-1265.

2. Müller, C.; Cramer, W.; Hare, W.L.; Lotze-Campen, H. Climate change risks for African agriculture. Proc. Natl. Acad. Sci. USA 2011, 108, 4313-4315. [CrossRef] [PubMed]

3. Cooper, P.; Dimes, J.; Rao, K.; Shapiro, B.; Shiferaw, B.; Twomlow, S. Coping better with current climatic variability in the rain-fed farming systems of Sub-Saharan Africa: An essential first step in adapting to future climate change? Agric. Ecosyst. Environ. 2008, 126, 24-35. [CrossRef]

4. Harvell, C.D.; Mitchell, C.E.; Ward, J.R.; Altizer, S.; Dobson, A.P.; Ostfeld, R.S.; Samuel, M.D. Climate warming and disease risks for terrestrial and marine biota. Science 2002, 296, 2158-2162. [CrossRef] [PubMed]

5. Serdeczny, O.; Adams, S.; Baarsch, F.; Coumou, D.; Robinson, A.; Hare, W.; Schaeffer, M.; Perrette, M.; Reinhardt, J. Climate change impacts in Sub-Saharan Africa: From physical changes to their social repercussions. Reg. Environ. Chang. 2016, 17, 1585-1600. [CrossRef]

6. Kaczan, D.; Arslan, A.; Lipper, L. Climate-Smart Agriculture, A Review of Current Practice of Agroforestry and Conservation Agriculture in Malawi and Zambia; ESA Working Paper No. 13-07; Food and Agriculture Organization of the United Nations (FAO): Rome, Italy, 2013.

7. Cohen, B. Urbanization in developing countries: Current trends, future projections, and key challenges for sustainability. Technol. Soc. 2006, 28, 63-80. [CrossRef]

8. Godfray, H.C.J.; Beddington, J.R.; Crute, I.R.; Haddad, L.; Lawrence, D.; Muir, J.F.; Pretty, J.; Robinson, S.; Thomas, S.M.; Toulmin, C. Food security: The challenge of feeding 9 billion people. Science 2010, 327, 812-818. [CrossRef] [PubMed]

9. McCarthy, N.; Lipper, L.; Branca, G. Climate-Smart Agriculture: Smallholder Adoption and Implications for Climate Change Adaptation and Mitigation; Climate Change Agriculture Work Paper; Food and Agriculture Organization of the United Nations (FAO): Rome, Italy, 2011; pp. 1-37.

10. Food and Agriculture Organization of the United Nations (FAO). "Climate-Smart" Agriculture: Policies, Practices and Financing for Food Security, Adaptation and Mitigation; Food and Agriculture Organization of the United Nations (FAO): Rome, Italy, 2010.

11. Lipper, L.; Thornton, P.; Campbell, B.M.; Baedeker, T.; Braimoh, A.; Bwalya, M.; Caron, P.; Cattaneo, A.; Garrity, D.; Henry, K.; et al. Climate-smart agriculture for food security. Nat. Clim. Chang. 2014, 4, 1068-1072. [CrossRef]

12. Campbell, B.M.; Thornton, P.; Zougmoré, R.; van Asten, P.; Lipper, L. Sustainable intensification: What is its role in climate smart agriculture? Curr. Opin. Environ. Sustain. 2014, 8, 39-43. [CrossRef]

13. Kpadonou, R.A.B.; Owiyo, T.; Barbier, B.; Denton, F.; Rutabingwa, F.; Kiema, A. Advancing climate-smart-agriculture in developing drylands: Joint analysis of the adoption of multiple on-farm soil and water conservation technologies in west African sahel. Land Use Policy 2017, 61, 196-207. [CrossRef]

14. Fernández-Baldor, Á.; Hueso, A.; Boni, A. From individuality to collectivity: The challenges for technology-oriented development projects. In The Capability Approach, Technology and Design; Oosterlaken, I., van den Hoven, J., Eds.; Springer: Dordrecht, The Netherlands, 2012; pp. 135-152. 
15. Zhou, K.Z.; Yim, C.K.; Tse, D.K. The effects of strategic orientations on technology-and market-based breakthrough innovations. J. Mark. 2005, 69, 42-60. [CrossRef]

16. Matta, N.F.; Ashkenas, R.N. Why good projects fail anyway. Harv. Bus. Rev. 2003, 81, 109-116. [PubMed]

17. Douthwaite, B.; Keatinge, J.D.H.; Park, J.R. Why promising technologies fail: The neglected role of user innovation during adoption. Res. Policy 2001, 30, 819-836. [CrossRef]

18. Van den Ende, J.; Dolfsma, W. Technology-push, demand-pull and the shaping of technological paradigms-patterns in the development of computing technology. J. Evol. Econ. 2005, 15, 83-99. [CrossRef]

19. Nam, C.H.; Tatum, C.B. Strategies for technology push: Lessons from construction innovations. J. Constr. Eng. Manag. 1992, 118, 507-524. [CrossRef]

20. Zijp, W. Improving the Transfer and Use of Agricultural Information: A Guide to Information Technology; World Bank Discussion Papers No. WDP 247; The World Bank: Washington, DC, USA, 1994.

21. Ndjeunga, J.; Bantilan, C. Uptake of improved technologies in the semi-arid tropics of West Africa: Why is agricultural transformation lagging behind? J. Agric. Dev. Econ. 2005, 2, 85-102.

22. Quisumbing, A.R.; Pandolfelli, L. Promising approaches to address the needs of poor female farmers: Resources, constraints, and interventions. World Dev. 2010, 38, 581-592. [CrossRef]

23. Hounkonnou, D.; Kossou, D.; Kuyper, T.W.; Leeuwis, C.; Nederlof, E.S.; Roling, N.; Sakyi-Dawson, O.; Traore, M.; van Huis, A. An innovation systems approach to institutional change: Smallholder development in West Africa. Agric. Syst. 2012, 108, 74-83. [CrossRef]

24. Roling, N.; Hounkonnou, D.; Kossou, D.; Kuyper, T.W.; Nederlof, S.; Sakyi-Dawson, O.; Traore, M.; van Huis, A. Diagnosing the scope for innovation: Linking smallholder practices and institutional context introduction to the special issue. NJAS-Wagening. J. Life Sci. 2012, 60-63, 1-6. [CrossRef]

25. Schut, M.; van Asten, P.; Okafor, C.; Hicintuka, C.; Mapatano, S.; Nabahungu, N.L.; Kagabo, D.; Muchunguzi, P.; Njukwe, E.; Dontsop-Nguezet, P.M.; et al. Sustainable intensification of agricultural systems in the central African highlands: The need for institutional innovation. Agric. Syst. 2016, 145, 165-176. [CrossRef]

26. Rosenstock, T.S.; Lamanna, C.; Chesterman, S.; Bell, P.; Arslan, A.; Richards, M.; Rioux, J.; Akinleye, A.; Champalle, C.; Cheng, Z.; et al. The Scientific Basis of Climate-Smart Agriculture: A Systematic Review Protocol; CCAFS Working Paper no. 138; CGIAR Research Program on Climate Change, Agriculture and Food Security (CCAFS): Copenhagen, Denmark, 2016.

27. Van Paassen, A.; Klerkx, L.; Adu-Acheampong, R.; Adjei-Nsiah, S.; Zannoue, E. Agricultural innovation platforms in west Africa: How does strategic institutional entrepreneurship unfold in different value chain contexts? Outlook Agric. 2014, 43, 193-200. [CrossRef]

28. Berrang-Ford, L.; Pearce, T.; Ford, J. Systematic review approaches for climate change adaptation research. Reg. Environ. Chang. 2015, 15, 755-769. [CrossRef]

29. Epule, E.T.; Ford, J.; Lwasa, S.; Lepage, L. Climate change adaptation in the sahel. Environ. Sci. Policy 2017, 75, 121-137. [CrossRef]

30. Reuters, T. Endnote x7; Thomson Reuters: Philadelphia, PA, USA, 2013.

31. Sumner, A. Global poverty and the new bottom billion: What if three-quarters of the world's poor live in middle-income countries? IDS Work. Pap. 2010, 2010, 1-43. [CrossRef]

32. Woolthuis, K.R.; Lankhuizen, M.; Gilsing, V. A system failure framework for innovation policy design. Technovation 2005, 25, 609-619. [CrossRef]

33. Van Mierlo, B.; Leeuwis, C.; Smits, R.; Woolthuis, R.K. Learning towards system innovation: Evaluating a systemic instrument. Technol. Forecast. Soc. 2010, 77, 318-334. [CrossRef]

34. Schut, M.; Rodenburg, J.; Klerkx, L.; van Ast, A.; Bastiaans, L. Systems approaches to innovation in crop protection. A systematic literature review. Crop Prot. 2014, 56, 98-108. [CrossRef]

35. R Core Team. R: A Language and Environment for Statistical Computing. Available online: http:/ / www.rproject.org/ (accessed on 8 June 2018).

36. Fischer, H.W.; Reddy, N.L.N.; Rao, M.L.S. Can more drought resistant crops promote more climate secure agriculture? Prospects and challenges of millet cultivation in Ananthapur, Andhra Pradesh. World Dev. Perspect. 2016, 2, 5-10. [CrossRef]

37. Hochman, Z.; Horan, H.; Reddy, D.R.; Sreenivas, G.; Tallapragada, C.; Adusumilli, R.; Gaydon, D.S.; Laing, A.; Kokic, P.; Singh, K.K.; et al. Smallholder farmers managing climate risk in India: 2. Is it climate-smart? Agric. Syst. 2017, 151, 61-72. [CrossRef] 
38. Khatri-Chhetri, A.; Aggarwal, P.K.; Joshi, P.K.; Vyas, S. Farmers' prioritization of climate-smart agriculture (CSA) technologies. Agric. Syst. 2017, 151, 184-191. [CrossRef]

39. Kritee, K.; Nair, D.; Tiwari, R.; Rudek, J.; Ahuja, R.; Adhya, T.; Loecke, T.; Hamburg, S.; Tetaert, F.; Reddy, S.; et al. Groundnut cultivation in semi-arid peninsular India for yield scaled nitrous oxide emission reduction. Nutr. Cycl. Agroecosyst. 2015, 103, 115-129. [CrossRef]

40. Sharma, R.; Chauhan, S.K.; Tripathi, A.M. Carbon sequestration potential in agroforestry system in India: An analysis for carbon project. Agrofor. Syst. 2016, 90, 631-644. [CrossRef]

41. Subash, N.; Gangwar, B.; Singh, S.; Koshal, A.K.; Kumar, V. Long-term yield variability and detection of site-specific climate-smart nutrient management practices for rice-wheat systems: An empirical approach. J. Agric. Sci. 2014, 152, 575-601. [CrossRef]

42. Alem, Y.; Eggert, H.; Ruhinduka, R. Improving welfare through climate-friendly agriculture: The case of the system of rice intensification. Environ. Resour. Econ. 2015, 62, 243-263. [CrossRef]

43. Kimaro, A.A.; Mpanda, M.; Rioux, J.; Aynekulu, E.; Shaba, S.; Thiong'o, M.; Mutuo, P.; Abwanda, S.; Shepherd, K.; Neufeldt, H.; et al. Is conservation agriculture 'climate-smart' for maize farmers in the highlands of tanzania? Nutr. Cycl. Agroecosyst. 2016, 105, 217-228. [CrossRef]

44. Msalya, G.; Lie, H.; Mfinanga, V.; Ringheim, A.S.; Sandvik, R.; Åsli, M.; Christophersen, O.A.; Haug, A.; Mushi, D.E.; Mwaseba, D.; et al. Public-private partnership for sustainable production and marketing of goat's milk in light of climate change. In Climate Change and Multi-Dimensional Sustainability in African Agriculture: Climate Change and Sustainability in Agriculture; Lal, R., Kraybill, D., Hansen, D.O., Singh, B.R., Mosogoya, T., Eik, L.O., Eds.; Springer: Cham, Switzerland, 2016; pp. 505-524.

45. Murage, A.W.; Midega, C.A.O.; Pittchar, J.O.; Pickett, J.A.; Khan, Z.R. Determinants of adoption of climate-smart push-pull technology for enhanced food security through integrated pest management in eastern Africa. Food Secur. 2015, 7, 709-724. [CrossRef]

46. Ajayi, A.E.; Horn, R. Transformation of ex-arable land to permanent grassland promotes pore rigidity and mechanical soil resilience. Ecol. Eng. 2016, 94, 592-598. [CrossRef]

47. Beyer, C.; Höper, H. Greenhouse gas exchange of rewetted bog peat extraction sites and a sphagnum cultivation site in northwest germany. Biogeosciences 2015, 12, 2101-2117. [CrossRef]

48. Böttcher, H.; Freibauer, A.; Scholz, Y.; Gitz, V.; Ciais, P.; Mund, M.; Wutzler, T.; Schulze, E.D. Setting priorities for land management to mitigate climate change. Carbon Balanc. Manag. 2012, 7, 5. [CrossRef] [PubMed]

49. Arakelyan, I.; Moran, D. Nationally appropriate mitigation actions for the dairy sector in malawi: Needs and opportunities. In Handbook of Climate Change Adaptation; Springer: Berlin/Heidelberg, Germany, 2015; pp. 1861-1882.

50. Branca, G.; Lipper, L.; Sorrentino, A. Cost-effectiveness of climate-related agricultural investments in developing countries: A case study. New Medit 2015, 14, 4-12.

51. Dougill, A.J.; Whitfield, S.; Stringer, L.C.; Vincent, K.; Wood, B.T.; Chinseu, E.L.; Steward, P.; Mkwambisi, D.D. Mainstreaming conservation agriculture in Malawi: Knowledge gaps and institutional barriers. J. Environ. Manag. 2017, 195, 25-34. [CrossRef] [PubMed]

52. Żukowska, G.; Myszura, M.; Baran, S.; Wesołowska, S.; Pawłowska, M.; Dobrowolski, Ł. Agriculture vs. Alleviating the climate change. Prob. Ekorozw. 2016, 11, 67-74.

53. Steenwerth, K.L.; Hodson, A.K.; Bloom, A.J.; Carter, M.R.; Cattaneo, A.; Chartres, C.J.; Hatfield, J.L.; Henry, K.; Hopmans, J.W.; Horwath, W.R.; et al. Climate-smart agriculture global research agenda: Scientific basis for action. Agric. Food Secur. 2014, 3, 11. [CrossRef]

54. Thierfelder, C.; Rusinamhodzi, L.; Setimela, P.; Walker, F.; Eash, N.S. Conservation agriculture and drought-tolerant germplasm: Reaping the benefits of climate-smart agriculture technologies in central mozambique. Renew. Agric. Food Syst. 2016, 31, 414-428. [CrossRef]

55. Thierfelder, C.; Matemba-Mutasa, R.; Bunderson, W.T.; Mutenje, M.; Nyagumbo, I.; Mupangwa, W. Evaluating manual conservation agriculture systems in Southern Africa. Agric. Ecosyst. Environ. 2016, 222, 112-124. [CrossRef]

56. Bandanaa, J.; Egyir, I.S.; Asante, I. Cocoa farming households in ghana consider organic practices as climate smart and livelihoods enhancer. Agric. Food Secur. 2016, 5, 29. [CrossRef]

57. Pulkkinen, H.; Roininen, T.; Katajajuuri, J.M.; Järvinen, M. Development of a climate choice meal concept for restaurants based on carbon footprinting. Int. J. Life Cycle Assess. 2016, 21, 621-630. [CrossRef] 
58. Neufeldt, H.; Jahn, M.; Campbell, B.M.; Beddington, J.R.; DeClerck, F.; De Pinto, A.; Gulledge, J.; Hellin, J.; Herrero, M.; Jarvis, A. Beyond climate-smart agriculture: Toward safe operating spaces for global food systems. Agric. Food Secur. 2013, 2, 12. [CrossRef]

59. Aby, B.A.; Kantanen, J.; Aass, L.; Meuwissen, T. Current status of livestock production in the nordic countries and future challenges with a changing climate and human population growth. Acta Agric. Scand. Sect. A-Anim. Sci. 2014, 64, 73-97.

60. Ajayi, O.C.; Catacutan, D. Role of externality in the adoption of smallholder agroforestry: Case studies from Southern Africa and Southeast Asia. In Externality: Economics, Management and Outcomes; Sunderasan, S., Ed.; Nova Science Publishers, Inc.: New York, NY, USA, 2012; pp. 167-188.

61. Brandt, P.; Kvakić, M.; Butterbach-Bahl, K.; Rufino, M.C. How to target climate-smart agriculture? Concept and application of the consensus-driven decision support framework "target CSA". Agric. Syst. 2017, 151, 234-245. [CrossRef]

62. Edjabou, L.D.; Smed, S. The effect of using consumption taxes on foods to promote climate friendly diets-The case of denmark. Food Policy 2013, 39, 84-96. [CrossRef]

63. Arslan, A.; McCarthy, N.; Lipper, L.; Asfaw, S.; Cattaneo, A.; Kokwe, M. Climate smart agriculture? Assessing the adaptation implications in zambia. J. Agric. Econ. 2015, 66, 753-780. [CrossRef]

64. Douxchamps, S.; Van Wijk, M.T.; Silvestri, S.; Moussa, A.S.; Quiros, C.; Ndour, N.Y.B.; Buah, S.; Somé, L.; Herrero, M.; Kristjanson, P.; et al. Linking agricultural adaptation strategies, food security and vulnerability: Evidence from west Africa. Reg. Environ. Chang. 2016, 16, 1305-1317. [CrossRef]

65. Carlsson, G.; Mårtensson, L.M.; Prade, T.; Svensson, S.E.; Jensen, E.S. Perennial species mixtures for multifunctional production of biomass on marginal land. GCB Bioenergy 2017, 9, 191-201. [CrossRef]

66. Saiz, G.; Wandera, F.M.; Pelster, D.E.; Ngetich, W.; Okalebo, J.R.; Rufino, M.C.; Butterbach-Bahl, K. Long-term assessment of soil and water conservation measures (Fanya-juu terraces) on soil organic matter in South Eastern Kenya. Geoderma 2016, 274, 1-9. [CrossRef]

67. Kibria, G.; Haroon, A.K.; Nugegoda, D. Climate change impacts on tropical and temperate fisheries, aquaculture, and seafood security and implications-A review. Livest. Res. Rural Dev. 2017, 29, 1-26.

68. Pillarisetti, J.R.; Tisdell, C. Multifunctional agriculture and wellbeing in developing nations. In Multifunctional Agriculture, Ecology and Food Security: International Perspectives; Pillarisetti, J.R., Lawrey, R., Ahmad, A., Eds.; Nova Science Publishers, Inc.: New York, NY, USA, 2013; pp. 1-19.

69. Ureta, J.U.; Evangelista, K.P.A.; Habito, C.M.D.; Lasco, R.D. Exploring gender preferences in farming system and tree species selection: Perspectives of smallholder farmers in Southern Philippines. J. Environ. Sci. Manag. 2016, 56-73.

70. Wong, S. Can climate finance contribute to gender equity in developing countries? J. Int. Dev. 2016, 28, 428-444. [CrossRef]

71. Bendito, A.; Twomlow, S. Promoting climate smart approaches to post-harvest challenges in Rwanda. Int. J. Agric. Sustain. 2015, 13, 222-239. [CrossRef]

72. De Nijs, P.J.; Berry, N.J.; Wells, G.J.; Reay, D.S. Quantification of biophysical adaptation benefits from climate-smart agriculture using a bayesian belief network. Sci. Rep. 2014, 4, 6682. [CrossRef] [PubMed]

73. Fader, M.; Shi, S.; Von Bloh, W.; Bondeau, A.; Cramer, W. Mediterranean irrigation under climate change: More efficient irrigation needed to compensate for increases in irrigation water requirements. Hydrol. Earth Syst. Sci. 2016, 20, 953-973. [CrossRef]

74. Case, S.D.C.; McNamara, N.P.; Reay, D.S.; Stott, A.W.; Grant, H.K.; Whitaker, J. Biochar suppresses $\mathrm{N}_{2} \mathrm{O}$ emissions while maintaining $\mathrm{N}$ availability in a sandy loam soil. Soil Biol. Biochem. 2015, 81, 178-185. [CrossRef]

75. Metz, B. International equity in climate change policy. Integr. Assess. 2000, 1, 111-126. [CrossRef]

76. Harris, P.G. Fairness, responsibility, and climate change. Ethics Int. Aff. 2003, 17, 149-156. [CrossRef]

77. Jost, C.; Kyazze, F.; Naab, J.; Neelormi, S.; Kinyangi, J.; Zougmore, R.; Aggarwal, P.; Bhatta, G.; Chaudhury, M.; Tapio-Bistrom, M.L.; et al. Understanding gender dimensions of agriculture and climate change in smallholder farming communities. Clim. Dev. 2016, 8, 133-144. [CrossRef]

78. Uddin, M.N.; Bokelmann, W.; Entsminger, J.S. Factors affecting farmers' adaptation strategies to environmental degradation and climate change effects: A farm level study in Bangladesh. Climate 2014, 2, 223-241. [CrossRef] 
79. Belay, A.; Recha, J.W.; Woldeamanuel, T.; Morton, J.F. Smallholder farmers' adaptation to climate change and determinants of their adaptation decisions in the central rift valley of Ethiopia. Agric. Food Secur. 2017, 6, 24. [CrossRef]

80. Rogers, P. Matching impact evaluation design to the nature of the intervention and the purpse of the evaluation. In Designing Impact Evaluations: Different Perspectives; Chambers, R., Karlan, D., Ravallion, M., Rogers, P., Eds.; International Initiative for Impact Evaluation: New Delhi, India, 2009; pp. 24-33.

81. Xiong, W.; van der Velde, M.; Holman, I.P.; Balkovic, J.; Lin, E.; Skalský, R.; Porter, C.; Jones, J.; Khabarov, N.; Obersteiner, M. Can climate-smart agriculture reverse the recent slowing of rice yield growth in China? Agric. Ecosyst. Environ. 2014, 196, 125-136. [CrossRef]

82. García de Jalón, S.; Silvestri, S.; Barnes, A.P. The potential for adoption of climate smart agricultural practices in Sub-Saharan livestock systems. Reg. Environ. Chang. 2017, 17, 399-410. [CrossRef]

83. Khatri-Chhetri, A.; Aryal, J.P.; Sapkota, T.B.; Khurana, R. Economic benefits of climate-smart agricultural practices to smallholder farmers in the indo-gangetic plains of India. Curr. Sci. 2016, 110, 1251-1256.

84. Bogdanski, A. Integrated food-energy systems for climate-smart agriculture. Agric. Food Secur. $2012,1,9$. [CrossRef]

85. Lognoul, M.; Theodorakopoulos, N.; Hiel, M.P.; Regaert, D.; Broux, F.; Heinesch, B.; Bodson, B.; Vandenbol, M.; Aubinet, M. Impact of tillage on greenhouse gas emissions by an agricultural crop and dynamics of $\mathrm{N}_{2} \mathrm{O}$ fluxes: Insights from automated closed chamber measurements. Soil Tillage Res. 2017, 167, 80-89. [CrossRef]

86. Njeru, P.N.M.; Maina, I.; Lekasi, J.K.; Kimani, S.K.; Esilaba, A.O.; Mugwe, J.; Mucheru-Muna, M. Climate smart agriculture adaptation strategies for rain-fed agriculture in drought-prone areas of Central Kenya. Int. J. Agric. Resour. Gov. Ecol. 2016, 12, 113-124. [CrossRef]

87. Chandra, A.; McNamara, K.E.; Dargusch, P.; Damen, B.; Rioux, J.; Dallinger, J.; Bacudo, I. Resolving the unfccc divide on climate-smart agriculture. Carbon Manag. 2016, 7, 295-299. [CrossRef]

88. Zougmoré, R.; Partey, S.; Ouédraogo, M.; Omitoyin, B.; Thomas, T.; Ayantunde, A.; Ericksen, P.; Said, M.; Jalloh, A. Toward climate-smart agriculture in west Africa: A review of climate change impacts, adaptation strategies and policy developments for the livestock, fishery and crop production sectors. Agric. Food Secur. 2016, 5, 26. [CrossRef]

89. Engel, S.; Muller, A. Payments for environmental services to promote "climate-smart agriculture"? Potential and challenges. Agric. Econ. (UK) 2016, 47, 173-184. [CrossRef]

90. Maharaj, R.; Singh-Ackbarali, D.; Sankat, C.K. Postharvest management strategies. In Impacts of Climate Change on Food Security in Small Island Developing States; IGI Global: Hershey, PA, USA, 2015; pp. 221-254.

91. Harvey, C.A.; Chacón, M.; Donatti, C.I.; Garen, E.; Hannah, L.; Andrade, A.; Bede, L.; Brown, D.; Calle, A.; Chará, J.; et al. Climate-smart landscapes: Opportunities and challenges for integrating adaptation and mitigation in tropical agriculture. Conserv. Lett. 2014, 7, 77-90. [CrossRef]

92. Descheemaeker, K.; Oosting, S.J.; Tui, S.H.K.; Masikati, P.; Falconnier, G.N.; Giller, K.E. Climate change adaptation and mitigation in smallholder crop-livestock systems in Sub-Saharan Africa: A call for integrated impact assessments. Reg. Environ. Chang. 2016, 16, 2331-2343. [CrossRef]

93. Li, X.G.; Jensen, K.L.; Clark, C.D.; Lambert, D.M. Consumer willingness to pay for beef grown using climate friendly production practices. Food Policy 2016, 64, 93-106. [CrossRef]

94. Beuchelt, T.D.; Badstue, L. Gender, nutrition- and climate-smart food production: Opportunities and trade-offs. Food Secur. 2013, 5, 709-721. [CrossRef]

95. Murage, A.W.; Pittchar, J.O.; Midega, C.A.O.; Onyango, C.O.; Khan, Z.R. Gender specific perceptions and adoption of the climate-smart push-pull technology in eastern Africa. Crop Prot. 2015, 76, 83-91. [CrossRef]

96. Khapung, S. Transnational feminism and women's activism: Building resilience to climate change impact through women's empowerment in climate smart agriculture. Asian J. Women's Stud. 2016, 22, 497-506. [CrossRef]

97. Akter, S.; Krupnik, T.; Rossi, F.; Khanam, F. The influence of gender and product design on farmers' preferences for weather-indexed crop insurance. Glob. Environ. Chang. 2016, 38, 217-229. [CrossRef] [PubMed]

98. Scholtz, M.M.; Schönfeldt, H.C.; Neser, F.W.C.; Schutte, G.M. Research and development on climate change and greenhouse gases in support of climate-smart livestock production and a vibrant industry. S. Afr. J. Anim. Sci. 2014, 44, S1-S7. 
99. Makate, C.; Wang, R.C.; Makate, M.; Mango, N. Crop diversification and livelihoods of smallholder farmers in Zimbabwe: Adaptive management for environmental change. Springerplus 2016, 5, 1135. [CrossRef] [PubMed]

100. Mottaleb, K.A.; Rejesus, R.M.; Murty, M.V.R.; Mohanty, S.; Li, T. Benefits of the development and dissemination of climate-smart rice: Ex ante impact assessment of drought-tolerant rice in South Asia. Mitig. Adapt. Strateg. Glob. Chang. 2017, 22, 879-901. [CrossRef]

101. Loughridge, K.B. Community Supported Agriculture (CSA) in the Mid-Atlantic United States: A Sociological Analysis. Ph.D. Thesis, North Carolina State University, Raleigh, NC, USA, 2003.

102. Shames, S.; Heiner, K.; Kapukha, M.; Kiguli, L.; Masiga, M.; Kalunda, P.N.; Ssempala, A.; Recha, J.; Wekesa, A. Building local institutional capacity to implement agricultural carbon projects: Participatory action research with VI agroforestry in Kenya and ecotrust in Uganda. Agric. Food Secur. 2016, 5, 13. [CrossRef]

103. Quail, S.; Onyango, L.; Recha, J.; Kinyangi, J. Private sector actions to enable climate-smart agriculture in small-scale farming in Tanzania. In Climate Change and Multi-Dimensional Sustainability in African Agriculture: Climate Change and Sustainability in Agriculture; Lal, R., Kraybill, D., Hansen, D.O., Singh, B.R., Mosogoya, T., Eik, L.O., Eds.; Springer: Cham, Switzerland, 2016; pp. 525-551.

104. Pomeroy, R.S.; Katon, B.M.; Harkes, I. Conditions affecting the success of fisheries co-management: Lessons from Asia. Mar. Policy 2001, 25, 197-208. [CrossRef]

105. Segnon, A.C.; Achigan-Dako, E.; Gaoue, O.; Ahanchédé, A. Farmer's knowledge and perception of diversified farming systems in sub-Humid and semi-arid areas in benin. Sustainability 2015, 7, 6573-6592. [CrossRef]

106. Campbell, B.M.; Vermeulen, S.J.; Aggarwal, P.K.; Corner-Dolloff, C.; Girvetz, E.; Loboguerrero, A.M.; Ramirez-Villegas, J.; Rosenstock, T.; Sebastian, L.; Thornton, P.; et al. Reducing risks to food security from climate change. Glob. Food Secur. 2016, 11, 34-43. [CrossRef]

107. Drucker, P.F.; Noel, J.L. Innovation and entrepreneurship: Practices and principles. J. Contin. High. Educ. 1986, 34, 22-23. [CrossRef]

108. Dalohoun, D.N.; Hall, A.; Mele, P.V. Entrepreneurship as driver of a 'self-organizing system of innovation': The case of Nerica in Benin. Int. J. Technol. Manag. Sustain. Dev. 2009, 8, 87-101. [CrossRef]

109. Boucher, O.; Forster, P.M.; Gruber, N.; Ha-Duong, M.; Lawrence, M.G.; Lenton, T.M.; Maas, A.; Vaughan, N.E. Rethinking climate engineering categorization in the context of climate change mitigation and adaptation. Wiley Interdiscip. Rev. Clim. Chang. 2014, 5, 23-35. [CrossRef]

110. Suckall, N.; Stringer, L.C.; Tompkins, E.L. Presenting triple-wins? Assessing projects that deliver adaptation, mitigation and development co-benefits in rural Sub-Saharan Africa. Ambio 2015, 44, 34-41. [CrossRef] [PubMed]

111. Anand, A.; Khetarpal, S. Impact of climate change on agricultural productivity. In Plant Biology and Biotechnology: Plant Diversity, Organization, Function and Improvement; Springer: New Delhi, India, 2015; Volume 1, pp. 729-755.

112. Klerkx, L.; Leeuwis, C. Establishment and embedding of innovation brokers at different innovation system levels: Insights from the dutch agricultural sector. Technol. Forecast. Soc. 2009, 76, 849-860. [CrossRef]

113. Cullen, B.; Tucker, J.; Snyder, K.; Lema, Z.; Duncan, A. An analysis of power dynamics within innovation platforms for natural resource management. Innov. Dev. 2014, 4, 259-275. [CrossRef]

114. Kedia, B.L.; Bhagat, R.S. Cultural constraints on transfer of technology across nations: Implications for research in international and comparative management. Acad. Manag. Rev. 1988, 13, 559-571. [CrossRef]

115. Kijima, Y.; Otsuka, K.; Sserunkuuma, D. An inquiry into constraints on a green revolution in Sub-Saharan Africa: The case of nerica rice in Uganda. World Dev. 2011, 39, 77-86. [CrossRef]

116. Baghel, R.; Nüsser, M. Discussing large dams in Asia after the World Commission on Dams: Is a political ecology approach the way forward? Water Altern. 2010, 3, 231-248.

117. Ahmed, I.I.; Lipton, M. Impact of Structural Adjustment on Sustainable Rural Livelihoods: A Review of the Literature; Institute of Development Studies and Poverty Research Unit, University of Sussex: Brighton, UK, 1997; p. 33.

118. Alexandratos, N.; Bruinsma, J. World Agriculture towards 2030/2050: The 2012 Revision; Food and Agriculture Organization of the United Nations: Rome, Italy, 2012; p. 160.

119. Biagini, B.; Miller, A. Engaging the private sector in adaptation to climate change in developing countries: Importance, status, and challenges. Clim. Dev. 2013, 5, 242-252. [CrossRef] 
120. Platteau, J.P. Physical infrastructure as a constraint on agricultural growth: The case of sub-Saharan Africa. Oxf. Dev. Stud. 1996, 24, 189-219. [CrossRef]

121. Haggblade, S.; Hazell, P.; Reardon, T. The rural non-farm economy: Prospects for growth and poverty reduction. World Dev. 2010, 38, 1429-1441. [CrossRef]

122. Rinaldi, S.M.; Peerenboom, J.P.; Kelly, T.K. Identifying, understanding, and analyzing critical infrastructure interdependencies. IEEE Control Syst. 2001, 21, 11-25. [CrossRef]

123. Siderius, C.; Boonstra, H.; Munaswamy, V.; Ramana, C.; Kabat, P.; van Ierland, E.; Hellegers, P. Climate-smart tank irrigation: A multi-year analysis of improved conjunctive water use under high rainfall variability. Agric. Water Manag. 2015, 148, 52-62. [CrossRef]

124. Olayide, O.E.; Tetteh, I.K.; Popoola, L. Differential impacts of rainfall and irrigation on agricultural production in Nigeria: Any lessons for climate-smart agriculture? Agric. Water Manag. 2016, 178, 30-36. [CrossRef]

(C) 2018 by the authors. Licensee MDPI, Basel, Switzerland. This article is an open access article distributed under the terms and conditions of the Creative Commons Attribution (CC BY) license (http:/ / creativecommons.org/licenses/by/4.0/). 